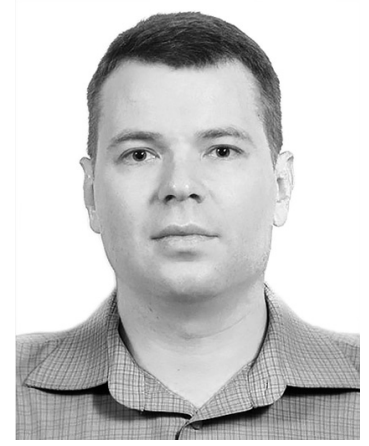

\title{
ПРОБЛЕМАТИКА АПРОКСИМАЦІї ЗАРУБІЖНОГО ДОСВІДУ ПРАВОВОГО РЕГУЛЮВАННЯ ІНФОРМАЦІЙНОӦ ДІЯЛЬНОСТІ ОРГАНІВ ПРОКУРАТУРИ
}

\author{
АМЕЛІН Олександр Юрійович - здобувач ПрАТ «ВНЗ «Міжрегіональна \\ Академія управління персоналом"
}

DOI:10.32782/NP.2020.1.6 https://orcid.org/0000-0002-0933-2111

Статья посвящена исследованию особенностей заимствования зарубежного опьта правового регулирования инбормачионной деятельности органов прокуратурьл. Автором проанализирован ряд нормативно-правовых актов международного и национального уровня, научнъе позиции и наработки отечественных ученъхх в области инбормаиионного, административного и международного права.

B прочессе исследования предпринята попьтка анализа категориального аппаpата. Изучение существующих подходов к пониманию определений «адаптаияля, «аппроксимачия», «гармонизачия», позволило определить их общие и отличительньие чертыл. Вылявлено, что несмотря на наличие в нормативно-правовъх актах всех въиеупомянутьх определений, очень часто они употребляются как тождественнъе, хотя имеют разнъие значения. В процессе ребормирования органов прокуратурь оптимальной является именно аппроксимачия - заимствования правовъгх норм, институтов, процедур, других элементов зарубежного опътта правового регулирования инбормаиионной деятельности прокуратуры, с целью повычшения ее эббективности, с учетом исторических, сочиальньхх, ментальньхх и других особенностей украинского народа.

Отдельное внимание посвящено реборме органов прокуратурьи, происходящей в русле адаптации украинского законодательства к стандартам EC. Автор обращает внимание на тот факт, что в отличии от ситуациии с органами прокуратурь, в прочессе ребормы образования законодатель (при поддержке Конституционного суда) позволяет себе игнорировать рекомендации Венецианской комиссии. Это создает прецедент, что позволяет надеяться на учет начиональньхх интересов в процессе дальнейшего реббормирования органов прокуратурьл.

Ключевъе слова: прокуратура, ребормирование, международнълй опьт, аппроксимаизи, адаптация, гармонизачия, инбормачионное право, Венецианская комиссия.

\section{Обгрунтування обраної}

теми дослідження

Европейський вектор розвитку України обумовлюе необхідність проведення комплексу заходів, спрямованих на формування в нашій державі таких правових, інституційних конструкцій, які відповідають високим стандартам країн-учасниць EC. Численні реформи, які не оминають практично жодної галузі, неможливі без активного вивчення, врахування, запозичення передового зарубіжного досвіду. Водночас, з огляду на історичні передумови, соціальні, економічні, політичні реалії сьогодення, мова не може йти про просте копіювання того чи іншого досвіду, насадження готової «ефективної» моделі. Без належного вивчення, врахування численних національних особливостей, той механізм, який дає високі результати в одній країні, може не лише не призвести до бажаного зростання, але й погіршити стан справ у іншій. 
Все це обумовлює потребу дослідження особливостей адаптації, апроксимації зарубіжного досвіду правового регулювання інформаційної діяльності органів прокуратури та специфіки гармонізації вітчизняного законодавства до стандартів EC.

Метою статті є дослідження особливостей запозичення зарубіжного досвіду правового регулювання інформаційної діяльності органів прокуратури в контексті відмінності дефініцій «апроксимація», «адаптація» та «гармонізація».

\section{Аналіз попередніх досліджень і публікацій}

Проблематиці запозичення іноземного досвіду правового регулювання інформаційної діяльності органів прокуратури в процесі їх реформування, присвячували свою увагу ряд вітчизняних вчених. Підгрунтям для даного дослідження стали окремі ідеї, напрацювання таких дослідників як: В. I. Аитвиненко, В. В. Аушер, С. В. Мазурик, А. М. Подоляка, С. А. Подоляка, В. С. Цимбалюк. Окрім того, в процесі дослідження враховано напрацювання дослідників проблематики апроксимації зарубіжного досвіду та законодавства, серед яких: С. В. Вишновецька, П. М. Рабінович, С. Р. Станік Т. С. Яровой. Водночас, висока динаміка реформаційних процесів, в поєднанні з відсутністю єдиної наукової концепції інформаційної діяльності органів прокуратури майбутнього, обмовлює потребу дослідження існуючих проблем запозичення провідного зарубіжного досвіду.

\section{Основний зміст дослідження}

Розгляд особливостей апроксимації зарубіжного досвіду регулювання діяльності органів прокуратури, доречно розпочати 3 уточнення дефініції «апроксимація». Необхідність уточнення термінології обумовлена поширенням близьких за змістом (але все ж - зовсім не ідентичних) визначень, як у чинному законодавстві так і серед наукової спільноти. Мова йде про дефініції «адаптація», «апроксимація» та «гармонізація». Так, зокрема, в Угоді про партнерство i співробітництво між Україною і Евро- пейськими Співтовариствами та їх державами-членами, ратифікованій Верховною Радою України у 1994 році, застосовуються такі характерні для норм права EC терміни як «адаптація» (статті 53, 77), «зближення» (статті 51, 76), «наближення» (стаття 60), «встановлення еквівалентних норм» (стаття 60) та «гармонізація» (статті 93, 129, 149, 150, 174 з Договору про Співтовариство) [1]. 3 огляду на це, доволі слушною видається думка С. В. Вишновецької, яка звертала свою увагу на питання правильності застосування термінів «наближення» та «зближення» в контексті приведення законодавства України у відповідність до законодавства EC, посилаючись на відмінності їх семантики [2]. Адже, наприклад, словник української мови трактує слово «наближатися, наближуватися» як переміщення одного об'єкта в напрямку до іншого: «переміщатися на ближчу віддаль до кого-, чого-небудь» [3, с. 17-18]. Натомість слово «зближатися, зближуватися» визначається як зустрічний рух кількох об'єктів: «переміщатися, рухатися, сходитись», або як процес досягнення певного уподібнення: «встановлювати зв’ язок, знаходити взаєморозуміння, вступати у взаємодію; ставати схожим, спорідненим» [4, с. 445-446]. Отже, коли мова заходить про внесення до українського законодавства змін, покликаних привести його у відповідність до законодавства EC, доречнішою буде дефініція «наближення» (з огляду на те, що зустрічного руху з боку законодавства $\mathrm{EC}$, чи навіть окремих країн-учасниць $\mathrm{EC,} \mathrm{до} \mathrm{законо-}$ давства України явно не передбачається).

Не додає однозначності трактування дефініцій і вітчизняний законодавець. У ряді нормативно-правових актів процес внесення змін до законодавства України, з метою приведення його у відповідність до законодавства EC, визначається як «адаптація» (з англ. adaptation - адаптація, пристосовування) [5]. При цьому сама дефініція «Адаптація законодавства України до законодавства Европейського Союзу» може визначатися як «процес зближення та поступового приведення законодавства України у відповідність до законодавства Европейського Союзу» [6]. А може розглядатися і як «пер- 
ший етап тривалого процесу наближення національної системи права, включаючи також правову культуру, доктрину та судову і адміністративну практику, до системи права Европейського Союзу відповідно до критеріїв, що висуваються Европейським Союзом щодо держав, які мають намір приєднатися до нього» [7, с. 168]. 3 огляду на семантичне наповнення, ми схильні вважати вірним другий підхід. Водночас, у такому разі «адаптація», як «початковий етап наближення», є складовою «апроксимації», як більш тривалого процесу, що супроводжується докорінними змінами.

Термін «апроксимація» теж не лишився поза увагою вітчизняної наукової спільноти Так, зокрема, С. Р. Станік вживає термін «апроксимація» у значенні наближення законодавчих актів України до правової системи Евросоюзу і вказує на апроксимацію як на творче використання (перейняття) норм європейського права [8, с. 29]. Водночас, частина юристів, які присвячували увагу досліджуваному питанню, надавали перевагу терміну «гармонізація». До цього терміну, зокрема, вдається Н. Р. Малишева, яка характеризує гармонізацію законодавства України з законодавством EC як таку, що обумовлена необхідністю адаптувати національну правову систему України до правового простору Европи [8, с. 89]. Схожу позицію висловлюе, П. М. Рабінович, який уточнюе, що гармонізація (гармонізування) - це процес приведення законодавства України у відповідність до правових систем провідних міжнародних організацій Европи [8, с. 255]. Більш слушним, на нашу думку, є зауваження В. I. Муравйова, який нагадує, що «здійснюючи гармонізацію, Україна повинна враховувати, що цей процес має однобічний характер, оскільки йдеться не про взаємні кроки з обох сторін щодо узгодження своїх правових норм, а тільки про зміни в українському законодавстві 3 метою його гармонізації з нормами Євросоюзу» [9, с. 266]. Підтримує таку позицію і Т. С. Яровой, додаючи при цьому, що «у рамках співпраці України з EC не йшла і не йде мова про якісь зміни у законодавстві EC, спрямовані на рух назустріч Україні. Українські науковці застосовують термін «гармонізація» для позначення однобічного процесу наближення внутрішнього законодавства з боку України до законодавства EC, хоча деякі з них і говорять про «зближення», а не «наближення» $[9$, с. $157]$.

Дефініції «адаптація» та «гармонізація» вживаються в різних значеннях і в затвердженій у 2005 році «Методиці визначення критеріїв євроінтеграційної складової державних цільових програм», відповідно до якої, адаптація законодавства (зближення) - це процес приведення законів України та інших нормативно-правових актів у відповідність із «асquis communautaire» (acquis communautaire - правова система EC, яка включає акти законодавства EC (але не обмежується ними), прийняті в рамках $\mathrm{EC}$, спільної зовнішньої політики та політики безпеки, співпраці у сфері юстиції та внутрішніх справ). Натомість, «гармонізація» (приведення у відповідність) - це процес приведення національних стандартів у відповідність із стандартами EC [10]. Хоча, як можна помітити, автори Методики теж схильні ототожнювати «зближення» та «наближення», що ми вважаємо не коректним.

Можна погодитися 3 К. В. Ященко, яка розглядає гармонізацію законодавства України до законодавства EC як складову частину адаптації. Термін «адаптація», на думку дослідниці, вживається у більш широкому значенні, ніж «наближення законодавств» і охоплюе не тільки проведення гармонізації та уніфікації законодавства України з законодавством EC, але й здійснення всього комплексу заходів, необхідних для приведення законодавства України у відповідність до вимог нормативно-правових актів EC [11, с. 57]. В такому контексті «адаптація» та «апроксимація» видаються тотожними дефініціями. Водночас, вони відрізняються за своєю метою. Як слушно зазначає з цього приводу Т. С. Яровой, «метою адаптації є приведення вітчизняного законодавства у відповідність до законодавства зарубіжного (або міжнародного, чи, скажімо, європейського). Натомість метою апроксимації є запозичення тих чи інших елементів зарубіжного (або міжнародного, чи, скажімо, європейського) 
законодавства для оптимізації відповідного національного законодавства [12, с. 158]. Також цікавою є думка М. В. Аушнікової, відповідно до якої, правова рецепція - це процес запозичення національною правовою системою правових цінностей, норм, інститутів, процедур, інших іноземних і міжнародних елементів правових систем 3 урахуванням рівня економічного і соціального розвитку держави, їі історичних традицій, правового менталітету, правової культури [13, с. 421]. Ми підтримуємо такий підхід до визначення дефініцій адаптація, апроксимація та рецепція. Однак, змушені констатувати, що у контексті реформування правоохоронної системи України в цілому та органів прокуратури зокрема, доречно вести мову саме про адаптацію зарубіжного та міжнародного досвіду, тоді як нам хотілося 6 спостерігати апроксимацію.

Наразі міжнародно-правові стандарти стосовно прокурорської діяльності та статусу прокурорів закріплені низкою нормативно-правових актів, зокрема: Рекомендацією $\operatorname{Rec}(2000) 19$ щодо ролі прокуратури в системі кримінального судочинства, ухваленою Комітетом міністрів Ради Европи 6 жовтня 2000 р. [14], Рекомендацією Парламентської Асамблеї 1604 (2003) щодо ролі прокуратури в демократичному суспільстві, керованому верховенством права, численними звітами Европейської Комісії «За демократію через право» та Рекомендацією CM/Rec(2012)11 щодо ролі державних прокурорів за межами системи кримінального судочинства, прийнятою Комітетом міністрів Ради Европи 19 вересня 2012 р. (Рекомендація CM/Rec(2012)11) [15] та іншими.

Певно, саме органи прокуратури, як жодні інші, відчувають на собі наслідки впровадження зарубіжного досвіду. За усталеною у вітчизняній законотворчій діяльності традицією, значну кількість змін, що відбулися у процесі реформування органів прокуратури, в тому числі - системне скорочення функцій прокуратури та обмеження повноважень прокурора, було обгрунтовано вимогами Ради Европи, зокрема численними висновками та рекомендаціями Европейської Комісії за демократію через право (Венеціанської комісії). Дійсно, ще у Висно- вку від 12-13 червня 2009 р. 3 приводу нагальної (на думку європейських експертів) потреби скорочення функцій прокуратури, зазначалося наступне: «Венеціанська комісія вже кілька разів висловлювала свою думки щодо чинного Закону України «Про прокуратуру». Закон від 5 листопада 1991 p. і законопроект від 14 липня 2000 р. коментувалися двома доповідачами Комісії (CDL(2001)128 і 134). По ще одному законопроекту Комісія затвердила свій висновок 8-9 жовтня 2004 р. (CDL-AD(2004)038). Пропоновані поправки до Конституції стосовно органів прокуратури були досліджені у висновку Комісії, прийнятому 13-14 жовтня 2006 р. (CDL-AD(2006)029)» [16]. Тобто Закон України «Про прокуратуру» від 5 листопада 1991 року, зазнавав систематичної критики Венеціанської комісії, яка передусім була орієнтована на необхідність обмеження повноважень прокурора. Як зазначалося у вже згаданому Висновку (від 12-13 червня 2009 р.) «У своїх попередніх висновках Венеціанська комісія вельми критично висловлювалася щодо закону про органи прокуратури в Україні. Комісія зазначила, що закон передбачає прокуратуру як «дуже потужний інститут, функції якого значно перевищують обсяг функцій, виконуваних прокурором у демократичній правовій державі». Цей інститут був названий прокуратурою радянського штибу (CDL-AD(2006)029. пп. 3 і 4)» [16]. Ці та інші висновки Венеціанської комісії були враховані в процесі розробки чинного Закону України «Про прокуратуру» [17], який значно обмежив функції органів прокуратури та повноваження прокурора, в тому числі стосовно права затребувати та отримувати інформацію від органів державної влади, органів місцевого самоврядування та підприємств, організацій, незалежно від форм власності (що було обумовлено усуненням функції «загального нагляду»).

Такий підхід вітчизняного законодавця видається цілком обгрунтованим. Незважаючи на дискусійність тих чи інших рішень, і навіть на можливі негативні наслідки від їх впровадження, стратегічний курс нашої держави на європейську інтеграцію вимагає врахування не лише вимог, але й ре- 


\section{Адміністративне право}

комендацій таких поважних інституцій як Рада Европи та Венеціанська комісія зокрема. Однак, викликає здивування той факт, що у інших випадках (наприклад - у процесі реформування системи освіти) законодавець дозволяє собі ігнорувати рекомендації Венеціанської комісії, знаходячи, при цьому, підтримку Конституційного суду України. Про що, зокрема, йдеться у Висновку Венеціанської комісії 6-7 грудня 2019 р.): «5 вересня 2017 року Верховна Рада прийняла Закон про освіту [18], який у своїй статті 7 регулює використання мов в освіті. Стаття 7 (що відображена у статті 21 Закону про державну мову) встановлює різні режими навчання мов та мовами корінних народів України, офіційних мов $\mathrm{EC}$ та мов національних меншин, які не є офіційними мовами EC. У своєму висновку 2017 року щодо статті 7 Закону про освіту (далі: «висновок 2017 року») Венеціанська комісія рекомендувала властям замінити статтю 7 на більш зважене та чітке положення. Крім того, Комісія дійшла до висновку, що менш сприятливе поводження з російською та іншими мовами, держави яких не є членами EC, важко обгрунтувати та порушує питання дискримінації. Однак Конституційний Суд України своїм рішенням № 10-r/2019 від 16 липня 2019 року оголосив Закон, включаючи статтю 7, недискримінаційним, а отже, конституційними [19, с. 7]. Таким чином, практика врахування рекомендацій Венеціанської комісії українським законодавцем не є послідовною, що є ще одним свідченням складності, неоднозначності проблематики апроксимації зарубіжного досвіду правового регулювання діяльності правоохоронних органів у цілому та органів прокуратури зокрема.

Аишається сподіватися, що спільні зусилля вітчизняних науковців, політиків та активної частини громадськості дозволять нам перейти від адаптації зарубіжного досвіду правового регулювання інформаційної діяльності прокуратури до його апроксимації.

\section{Висновки}

Запозичення зарубіжного досвіду може мати різні форми, відмінність між якими не надто помітна без належного аналізу. Мова йде про такі формати запозичення досвіду як «адаптація», «апроксимація», «гармонізація», «рецепція».

Хоча в численних нормативно-правових актах та наукових працях ідеться саме про апроксимацію зарубіжного досвіду правового регулювання діяльності органів прокуратури, наразі має місце не а апроксимація, а радше адаптація такого досвіду, оскільки даний процес характеризується односторонніми змінами вітчизняного законодавства в напрямку його пристосування до відносно усталеного законодавства EC в цілому та країн-учасниць EС зокрема.

В ідеалі ж, апроксимація зарубіжного досвіду правового регулювання інформаційної діяльності прокуратури, має являти собою запозичення правових норм, інститутів, процедур, інших елементів зарубіжного досвіду правового регулювання інформаційної діяльності прокуратури, 3 метою підвищення ефективності діяльності органів прокуратури України, з урахуванням історичних, соціальних, ментальних та інших особливостей українського народу.

\section{Література}

1. Угода про партнерство і співробітництво між Україною i Европейськими Співтовариствами та їх державами-членами: ратифіковано Законом № 237/94-ВР ( 237/94-ВР ) від 10.11.94p. Офіційний сайт Верховної Ради України [Електронний ресурс]. URL: https://zakon.rada.gov.ua/laws/ show/998_012

2. Вйшновецька С. В. Методологічні передумови гармонізації трудового законодавства України із законодавством EC // Соціально-економічні та правові підстави вдосконалення трудового законодавства на сучасному етапі: матеріали міжнародної науково-практичної конференції (м. Хмельницький, 21 жовтня 2016 р.). Хмельницький: Хмельницький ун-т упр-ня та права, 2016. С. 82-88.

3. Словник української мови. Київ, Наукова думка, 1974. Т. 5. 840 с.

4. Словник української мови. Київ, Наукова думка, 1972. Т. 3. 744 с.

5. Англо-український словник. [Електронний ресурс]. URL: https://www.dict.com/ англіисько-украінськии/adaptation 
6. Про Концепцію адаптації законодавства України до законодавства Европейського Союзу: Постанова Кабінету Міністрів України від 16 серпня 1999 р. № 1496 // Офіційний вісник України. 1999. № 33. C. 1735.

7. Послання Президента України до Верховної Ради України. Про внутрішне та зовнішне становище України у 2002 році. Київ. Інформаційно-видавничий центр Держкомстату України, 2003. Офіційне видання. 478 с.

8. Проблеми гармонізації законодавства України з міжнародним правом: Матеріали науково-практичної конференції. Інститут законодавства Верховної Ради України. Київ, 1998. 300 с.

9. Муравйов В. І. Правові засади регулювання економічних відносин Европейського Союзу з третіми країнами (теорія і практика). Київ. Академ-Прес, 2002. 425 с.

10. Про затвердження Методики визначення критеріїв євроінтеграційної складової державних цільових програм: Наказ Міністерства економіки та 3 питань Европейської Інтеграції України № 62 від 16.03.2005p. Офіційний сайт Верховної Ради України [Електронний ресурс]. URL: https://zakon.rada.gov.ua/laws/show/z0438-05/ ed20050508/find? text $=\% \mathrm{C} 3 \% \mathrm{E} 0 \% \mathrm{~F} 0 \% \mathrm{EC} \% \mathrm{E}$ E\%ED\%B3\%E7\% $0 \%$ F6\%B3\% FF+\%28\%EF\% F0\%Е8\% $2 \% \mathrm{E} 5 \% \mathrm{E} 4 \% \mathrm{E} 5 \% \mathrm{ED} \% \mathrm{ED} \% \mathrm{FF}+\% \mathrm{~F} 3$ +\% $2 \% \mathrm{~B} 3 \% \mathrm{E} 4 \% \mathrm{EF} \% \mathrm{EE} \% \mathrm{E} 2 \% \mathrm{~B} 3 \% \mathrm{E} 4 \% \mathrm{ED} \%$ $\mathrm{B} 3 \% \mathrm{~F} 1 \% \mathrm{~F} 2 \% \mathrm{FC} \% 29$

11. Ященко К. Місце гармонізації в процесі адаптації законодавства України до законодавства Європейських Співтовариств // Український часопис міжнародного права. 2003. № 1. С. 55-61.

12. Яровой Т. С. Зарубіжний досвід регулювання лобізму: проблематика апроксимації та адаптації / Т. С. Яровой. // Право та державне управління : зб. наук. пр. - Запоріжжя : вид-во Класичний приватний університет. - 2019. - № 4. - С. 153-160.

13. Аушникова М. В. Влияние процессов правовой глобализации на стратегию заимствования международного и зарубежного опыта правового регулирования трудовых отношений // Юридическая техника. 2015. № 9. C. 418-424.

14. Рекомендація Rec (2000) 19 Комітету Міністрів Ради Европи державам-членам щодо ролі прокуратури в системі кримінального правосуддя Ухвалено Комітетом Міністрів Ради Европи на 724 засіданні заступників міністрів 6 жовтня 2000 року URL: https://supreme.court.gov.ua/userfiles/ Rec $2000192000106 . p d f$

15. Рекомендація $\operatorname{Rec}(2012) 11$ Комітету міністрів державам-учасникам «Про роль публічних обвинувачів поза системою кримінальної юстиції (Прийнята Комітетом Міністрів 19 вересня 2012 на 1151-му засіданні заступників міністрів) [Електронний pecypc] URL: https://www.pravo.org.ua/files/ rec chodo publ.PDF

16. Европейська комісія «За демократію через право» (Венеціанська комісія): Висновок щодо проекту Закону України «Про прокуратуру» Затверджений на 79ому пленарному засіданні Венеціанської комісії (Венеція, 12-13 червня 2009 р.) [Електронний ресурс] URL: https://minjust. gov.ua/m/str_23374

17. Про прокуратуру : Закон України від 14.10.2014p. № 1697-VII. База даних «Законодавство України». Верховна Рада України. Офіційний Веб-портал URL: http://zakon.rada.gov.ua/go/1697-18

18. Про освіту Закон України від 05.09.2017 № 2145-VIII База даних «Законодавство України». Верховна Рада України. Офіційний Веб-портал URL: https:// zakon.rada.gov.ua/laws/show/2145-19

19. Висновок щодо Закону про забезпечення функціонування української мови як державної прийнятий Венеціанською Комісією на 121-ому пленарному засіданні (Венеція, 6-7 грудня 2019 р.) https://kmksz. com.ua/wp-content/uploads/2019/12/Висновок-венеціанської-комісії-960-2019.pdf

\section{PROBLEMS OF APPROXIMATION OF FOREIGN EXPERIENCE OF LEGAL REGULATIONS OF INFORMATION ACTIVITY OF PROSECUTOR'S OFFICES}

The article is devoted to the study of peculiarities of borrowing foreign experience of legal regulation of information activity of prosecutor's offices. The author analyzes a number of normative-legal acts of international and national level, scientific positions and achievements of national scientists in the field of information, administrative and international law.

In the course of the research an attempt was made to analyze the concept apparatus. Studying the existing approaches to under- 


\section{Адміністративне право}

\section{АНОТАЦІЯ}

Статтю присвячено дослідженню особливостей запозичення зарубіжного досвіду правового регулювання інформачійної діяльності органів прокуратури. Автором проаналізовано ряд нормативно-правових актів міжнародного та національного рівня, наукові позициї та напрацювання вітчизняних вчених у галузі інбормаиійного, адміністративного та міжнародного права.

В процесі дослідження здійснено спробу аналізу понятійного апарату. Вивчення існуючих підходів до розуміння визначень «адаптація», «апроксимація», «гармонізачія», дозволило визначити їх спільні та відмінні риси. Виявлено, що незважаючи на наявність у нормативно-правових актах всіх вищезазначених дебініиій, дуже часто вони вживаються як тотожні, хоча мають різні значення. У прочесі ребормування органів прокуратури оптимальною $є$ саме апроксимачія - запозичення правових норм, інститутів, процедур, інших елементів зарубіжного досвіду правового регулювання інбормаційної діяльності прокуратури, з метою підвищення ї̈ ебективності, з урахуванням історичних, сочіальних, ментальних та інших особливостей українсъкого народу.

Окрему увагу присвячено ребормі органів прокуратури, що відбувається в руслі адаптациї украӥнсъкого законодавства до стандартів EC. Автор звертає увагу на той бакт, що на відміну від ситуащй з органами прокуратури, у процесі реборми освіти законодавець (за підтримки Конституиійного суду) дозволяе собі ігнорувати рекомендациї Венеціансъкої комісї. Це створює прецедент, що дозволяє сподіватися на врахування начіональних інтересів у процесі подальшого ребормування органів прокуратури.

Ключові слова: прокуратура, ребормування, міжнародний досвід, апроксимачія, адаптачія, гармонізачія, інбормачійне право, Венеціансъка комісія. standing the definitions of "adaptation", "approximation", "harmonization" allowed us to identify their common and distinguishing features. It is revealed that despite the presence in the legal acts of all the above definitions, very often they are used as identical, although they have different meanings. In the process of reforming the prosecutor's office, the approximation is optimal - borrowing legal norms, institutes, procedures, and other elements of foreign experience of regulating the information activity of the prosecutor's office in order to increase its efficiency, taking into account historical, social, mental and other peculiarities of the Ukrainian people.

Particular attention is paid to the reform of the prosecution bodies, which is in the process of adapting Ukrainian legislation to EU standards. The author draws attention to the fact that, unlike the situation with the prosecuting authorities, in the process of education reform the legislator (with the support of the Constitutional Court) allows himself to ignore the recommendations of the Venice Commission. This creates a precedent that allows one to hope for national interests to be taken into account in the process of further reform of the prosecuting authorities.

Key words: prosecutor's office, reform, international experience, approximation, adaptation, harmonization, information law, Venice Commission. 